|Araştırma Makalesi / Research Article |

\title{
Öğretmenlerin Mesleki İnançları ile Öğrencilerin Problem Çözmeye Yönelik Tutumları Arasındaki ilişki: İsteklilik, Sebat ve Güven
}

\section{The Relationship between Teachers 'Professional Beliefs and Students' Attitudes towards Problem Solving: Willingness, Persistence and Confidence}

\section{Elif Kılıçoğlu ${ }^{1}$, Oktay Erbay ${ }^{2}$}

\begin{abstract}
Anahtar Kelimeler matematik eğitimi mesleki inanç temel eğitim

ilkokul öğrencileri

korelasyonel ilişki tarama
\end{abstract}

Keywords
mathematics education
professional belief
elementary education
primary school students
correlational screening
Başvuru Tarihi/Received
10.02.2020
Kabul Tarihi /Accepted
27.04.2020

Öz

Bu çalışmada öğretmenlerin mesleki inançları ile öğrencilerin problem çözmeye yönelik tutumları arasında ilişkinin olup olmadığı incelenmiştir. Burada ifade edilen problem çözmeye yönelik tutum kavramı isteklilik, sebat ve güven kategorileri ile temsil edilmektedir. Araştırma bir devlet ilkokulunun 4. sınıfında öğretime devam eden 12 tane sınıf öğretmeni ve öğrenime devam eden 395 öğrenci ile gerçekleştirilmiştir. Nicel araştırma türlerinden ilişkisel tarama modeline göre yapılan bu çalışmada veriler iki tür ölçek ile elde edilmiştir: öğretmenlere uygulanan mesleki inanç ölçeği ve öğrencilere uygulanan problem çözme tutum envanteri. Veri analizinde betimsel ve çıkarımsal istatistik kullanılmıştır. Analiz sonuçları öğretmenlerin mesleki inançlarının duyuşsal ve davranışsal boyutta yoğunlaştığını göstermektedir. Ayrıca öğretmenlerin mesleki inançları ile öğrencilerin problem çözmeye yönelik tutumları arasında iki değişkenin de alt boyutları çerçevesinde ilişki bulunmuştur.

Abstract

In this study, it was investigated whether there is a relationship between teachers 'professional beliefs and students' attitudes towards problem solving. The concept of attitude towards problem solving expressed here is represented by the categories of willingness, persistence and confidence. The research was carried out with 12 classroom teachers who continue their education in the 4th grade of a public primary school and 395 students who continue their education. In this study, which was conducted according to the relational screening model, which was one of the quantitative research types, the data were obtained with two types of scales: professional belief scale applied to teachers and problem solving attitude inventory applied to students. Descriptive and inferential statistics were used in the data analysis. The results of the analysis show that teachers' professional beliefs are concentrated in affective and behavioral dimensions. In addition, a relationship was found between teachers 'professional beliefs and students' attitudes towards solving promlem within the framework of the sub-dimensions of both variables.

\section{INTRODUCTION}

${ }^{1}$ Sorumlu Yazar, Hatay Mustafa Kemal University, Education Faculty, Hatay, Turkey, https://orcid.org/0000-0001-7904-4310

${ }^{2}$ Hatay Mustafa Kemal University, Education Faculty, Hatay, Turkey, https://orcid.org/0000-0002-2698-0129

Kılıçoğlu, E., \& Erbay, O. (2020). The relationship between teachers 'professional beliefs and students' attitudes towards problem solving: willingness, persistence and confidence. Kastamonu Education Journal, 28(4), 1882-1891. doi: 10.24106/kefdergi.772493 
The teacher is undoubtedly one of the most important elements of the education system. Barber and Mourshed (2007) state that the quality of the education system can only be predicted by the quality of teachers. Therefore, the role assigned to the teacher is very important. What are these roles?

It envisaged the change and development of the roles of teachers in the developing world conditions in our education system. It is clear that the teacher should have responsibilities beyond the tasks of transmitting and measuring information. The Ministry of National Education (2018) described these requirements as vocational qualifications. Professional competence includes the qualifications required by teachers to perform their profession properly. These qualifications are essential for better education. The teacher should support the creative thinking of the student, take the effort further, take into consideration the differences between students, create a positive learning environment, behave at equal distance to each individual. What makes the teacher important is that he is responsible for future of the students. This situation leads to the idea that teachers should have high level qualifications. As a matter of fact, MoNE (2018) states that teachers should have high qualifications because they are interested in individuals. In this sense, it can be said that teachers have various roles such as improving classroom atmosphere, shaping education, implementing activities and planning, evaluating and managing activities. Sünbül (1996) states that various classifications are made by various researchers about teacher roles. The classification of teacher roles is not the subject of this research. However, it is the subject of this study that teachers' roles according to this constructivist philosophy may be directly related to their professional beliefs.

The teacher's style of teaching shapes his roles. In other words, the roles of the teacher constitute their own style. The role, style and style of the teacher are concepts related to their personal development regardless of how this situation is expressed. The personal development of the teacher has an important role in shaping the professional belief. As a matter of fact, according to Chong and Low (2009), the responses of teachers to the situations they encounter from education process explain the concept of professional belief. Moreover, this concept is accepted as one of the main determinants of student success (Ernest, 1989; Lotter, Harwood and Bonner, 2007). Therefore, this makes the researches that investigate how teachers' professional beliefs shape the cognitive and affective characteristics of the students valuable. On the other hand, Brown and Cooney (1982) stated that professional belief is closely related to cognition; Pajares (1992) argues that professional belief is a very valuable psychological state. That is, it is important to reveal both cognitive and affective behaviors of teachers - this can also be expressed as revealing their professional beliefs - in terms of contributing more to the interpretation of the results. In addition, a limited number of studies on teachers' professional beliefs are found in the literature (Calderhead, 1996; Clark and Peterson, 1986; Kane, Sandretto and Heath, 2002; Pajares, 1992). Considering that teachers 'beliefs are the most important determinant of students' success, it can be stated that these studies are not sufficient. In this respect, the contribution of this research to the literature is clear. In this study, it is aimed to reveal the professional beliefs of classroom teachers and to determine whether this is related to students' attitudes. For this purpose, the following problems were sought:

1. How do 4th grade students' problem solving attitudes change along with their teachers' levels of professional beliefs?

2. Is there a relationship between the teachers 'professional beliefs and students' problem solving attitudes?

a. Is there a relationship between the elementary school teachers 'professional belief sub-dimensions?

b. Is there a relationship between the elementary students' problem solving attitudes sub-dimensions?

c. Is there a relationship between the elementary school teachers 'professional belief sub-dimensions and the students' problem solving attitudes sub-dimensions?

3. What is the collective effect of teacher belief subdimension scores on classes' problem solving attitude averages?

\section{Theoretical Framework}

\section{Professional Belief}

MoNE (2017) emphasized the professional skills of teachers when talking about teacher qualifications. Teachers' professional skills and planning, creation, management and evaluation of education in general are expressed. The most important concept that shape the behavior of the teacher in the course is his beliefs. The teacher shapes his actions according to his beliefs. As a matter of fact, Pajares (1992) states that the belief concept is very important for the individual and it is a concept that determines teachers' classroom practices and decisions and naturally creates the lesson plan.

According to Chan (2004), teachers' understanding of education is similar to their beliefs. Here, the whole understanding of the students' learning processes from the decisions to be taken about the teaching and learning process is expressed. In addition, teachers 'professional beliefs are affected by many variables related to education such as students' cognitive and affective characteristics, curriculum, classroom atmosphere (Guskey, 1988; Podell and Soodak, 1993; Woolfolk, Rosoff and Hoy, 1990). Because the concept of belief is not a closed structure, but rather it is quite open to external factors and can be affected and changed very quickly from any situation. Therefore, it is important to determine and control the variables that may affect teachers' professional beliefs. In addition, professional beliefs are the most effective way of making decisions about teachers (Enyedy, Goldberg and Welsh, 2005). Moreover, the structuring of teacher education system in this way is accepted scientifically (Kagan, 1992; Richardson, Anders, Tidwell and Lloyd, 1991). 
Considering that teachers' beliefs shape teaching, it becomes even more important to determine the correctness and inaccuracy of their beliefs. Because while the belief structure is difficult to change, changing the consequences of false beliefs becomes more challenging especially in the education and training process. For example, a teacher who relies on his / her knowledge headformost can restrict many behaviors in the classroom. Richardson (1996) stated that teachers perceive themselves as transmitting knowledge as it creates dangerous consequences for education. Decisions taken by teachers with such false beliefs are binding on each element of the education system and may bring about many negative situations. But teachers' beliefs can be changed through a well-planned education process (Zeichner, 1983). Although it was stated that belief existed in an individual in the past and negative beliefs were gained before the teacher education process started, and it was difficult to change this situation (Pajares, 1992). In other words, it is clear that the beliefs gained in the past before starting teacher education shape teachers own professional development. Considering that negative beliefs were gained before starting university, it can be stated that the concept of belief was shaped while still a student. The most important factor that can affect a student's belief is teachers. Therefore, this resembles a vicious circle and ultimately gives the teacher great responsibilities.

\section{Attitude Towards Problem Solving}

Problem solving is one of the skills that are actively involved in an individual's life from an early age. In particular, mathematical problem solving skills are often included in the curriculum as gains (MoNE, 2018). It is a dynamic structure that includes different mathematical skills not only in the school curriculum but also in problem solving skill structure which is actively involved in daily life and other disciplines. For example, a student who solves a mathematical problem can also use different skills such as communication, establishing relationships between concepts, making proof, making inferences and generalizations. For example, it is a problem to show that the sum of two odd numbers is an even number. To solve this problem, the student uses skills such as experiment, generalization, proof, correlation of results, modeling. What is expressed here as a problem is an intriguing situation or event. Olkun and Toluk Uçar (2012) state the problem as a situation that arouses the desire to solve in individual and individual solves the problem with his own experience.

Problem solving is not an ordinary process but a process with systematic steps. Polya (1957) states that this process can be explained in four steps: understanding the problem, determining the plan, implementing the plan and returning. These steps are not separated from each other in strict lines. The student has the freedom to solve the problem with his own method. Problem solving is a superior skill in terms of giving students the opportunity of creativity and in this respect it is suitable for the constructivist approach. In this process, teachers should support students' different approaches, create free environments for expressing their opinions, offer collaborative work opportunities and take individual differences into account. Failure to pay attention to these features may pave the way for the problem-solving process to encounter negativities. Because students may not always find creative solutions, or they may face a difficult process. These situations often result in students' negative attitudes towards problem solving. It is also true to say the opposite. Students' positive experiences related to problems also positively affect their attitude towards mathematics. The study conducted by Chapman (1997) shows that students' affective skills affect problem solving skills.

Ornstein and Lasley (2000) found a difference between attitudes of students who were successful and not successful in problem solving towards problem solving. According to this study, it is inevitable that the frustration experienced by unsuccessful students results in insecurity and this insecurity repeats for every problem situation encountered. According to Putnam, Lambert and Paterson (1990), problem solving knowledge and understanding mathematics are equivalent. In this respect, the attitude developed about problem solving skills becomes even more important. The American National Council of Mathematics Teachers (NCTM, 2000) draws attention to the fact that students should be good problem solvers. The way to achieve this goal is primarily by ensuring that the students are prepared emotionally.

\section{METHOD}

In this section, research model, selection of participants, measurement tools, data collection and analysis, validity and reliability analyzes are given.

\section{Research Design}

In this study, relational screening methods were used in quantitative research types. In relational screening, the researcher aims to determine the degree of change between two or more variables (Karasar, 2016). This model is made in two types as comparison and correlational (Büyüköztürk, 2016; Frankel, Wallen and Hyun, 2012). In the comparative screening model, firstly the variables are described and the results obtained by comparison are evaluated. In correlation, it is checked whether the variables change together and no intervention is made to the variables. In this study, teachers 'professional belief levels and students' willingness to solve problems, persistence and trust relationships were examined and it was intended to find out how variables change together. Therefore, this study is a correlational type of relational screening models. 


\section{Participant}

The study was carried out in 2018-2019 academic year, a government primary schools in Turkey's Hatay province. Twelve 4th grade teachers and their students participated in the study. The total number of students included in the study was 395. Appropriate sampling method was used to identify the participants. Appropriate sampling method is a sampling method that provides high participation with low cost and time saving (McMillan \& Schumacher, 2014; p. 240). In addition, it was considered appropriate to carry out the study at the 4th grade level of the primary school with the idea that more reliable data would be obtained in terms of responding to the measurement tools used in the research. On the other hand, the fact that mathematical problem building and solving skills were more intensely included in the 4th grade mathematics curriculum also supported the idea that the study should be conducted at this level. In this study, volunteers of both teachers and students were taken into consideration and they were informed that their personal information would not be shared with anyone.

\section{Measures}

Two types of scales were used to question the relationship between students 'problem solving process in mathematics and teachers' professional beliefs: professional belief scale and problem attitude inventory. For the reliability study of problem attitude inventory scale, 395 students' data was used. Field (2009) states that Cronbach's Alpha value should be .70 and above for the reliability of the measurement tools.

\section{Professional Belief Scale}

In order to determine the professional beliefs of the teachers, Teacher Belief Scale developed by Ozgen (2012) was used. According to the results of factor analysis, the scale consists of six factors: affective, behavioral, developmental, institutional, cognitive and education. The total explained variance of the scale was found to be $53.71 \%$. Reliability analysis for each subdimension was conducted and the overall reliability of the scale was calculated as 0.96 in original study (Table 1). Because of the limited number of teacher participants of this study, 12 teachers, cronbach alpha could not be calculated. Therefore, reliability level of this measure assumed to be same as the Ozgen (2012)'s study. This number shows us that the scale is very reliable.

Table 1. Data on the subdimensions of the teacher belief scale

\begin{tabular}{lccc}
\hline Subdimension & Cronbach Alpha & Explained Variance (\%) & Number of Items \\
\hline Affective & 0.955 & 20.2 & 21 \\
Behavioral & 0.928 & 13.8 & 13 \\
Development & 0.751 & 6.3 & 8 \\
Institutional & 0.662 & 5.2 & 3 \\
Cognitive & 0.622 & 4.8 & 5 \\
Education & 0.601 & 3.5 & 3 \\
\hline
\end{tabular}

As seen in Table 1, the scale consists of 21 items in affective dimension, 13 in behavioral dimension, 8 in development dimension, 3 in institutional dimension, 5 in cognitive dimension and 3 in education dimension. The scale is of 5-point Likert type, I strongly agree, agree, undecided, disagree, and strongly disagree.

\section{Problem Solving Attitude Inventory}

Budak (2007) adapted the problem-solving attitude inventory developed by the University of Indiana for the mathematics project (Charles et al., 1987, p. 27) into Turkish. In this study, the scale which was adapted by Budak (2007) was used. Inventory has three factors: willingness, persistence and self-confidence. Here, with the willingness factor, students' willingness to participate in mathematics problems; behavior in the process of persistence and problem solving; self-confidence is also meant to approach the problem. In the inventory, there are 20 items, 6 in willingness factor, 6 in persistence factor, 8 in self-confidence factor. 9 of these items are positive and 11 of them are negative. In the inventory, yes score is given as 1 and no score is given as 0 . For the reliability of the inventory, researcher made two applications to 6th grade students at regular intervals (Budak, 2007). Applications were evaluated separately for all three factors of the inventory. Persistence factor alone had a $44 \%$ effect on total variance and $86 \%$ with confidence $\left(R^{2}=.86, F(1,29)=87.41, p<.001\right)$. It was stated that the willingness factor had less predictive power despite the persistence and confidence factor. Therefore, it was said that the persistence and confidence factors should be taken into consideration in the evaluation. In this study, 395 student data was used and for the reliability study of problem solving attitude inventory. Cronbach reliability of sclaes found to be 0.732 for willingness, 0.644 for persistence, 0.712 for confidence, and 0.829 for all inventory. 


\section{Data Analysis and Procedure}

The data obtained in this study were analyzed with descriptive and inferential methods. While descriptive analysis is an analysis method that includes summary tables that make the quantitative data appear to be more compact; inferential analysis is an analysis that helps to predict the population based on the data obtained at the end of the research (McMillan \& Schumacher, 2014). For descriptive analysis, descriptive statistical data of each variable were obtained, and for the inferential analysis, explanations were made about the relationship between the variables. SPSS 20 program was used for the analysis of the obtained data. Before the analysis, it was examined whether the data showed normal distribution. All data were found to be normal distribution and Pearson correlation coefficient was used for the correlation value. Values expressed by Schober, Boer and Schwarte (2018) are taken as reference for the interpretation of the significance level of the relationship. According to this study, the levels and comments are as follows: 0.00-0.10 negligible correlation, 0.10-0.39 weak correlation, 0.40-0.69 moderate correlation, $0.70-0.89$ strong correlation, $0.90-1.00$ very strong correlation.

Necessary permissions were obtained from MoNE for the implementation of this study. The application was made primarily to teachers. Since the professional belief scale is a 70-item scale, there is no restriction on time for teachers. Flexibility has been shown to interrupt the application in case of fatigue for the reliability of the answers. The application of the students was carried out within one hour.

\section{Reliability and Validity of the Data}

The reliability and validity of the instruments used in the study are directly related to the validity and reliability of the research. The application and data analysis process has been meticulously handled for the validity and reliability of the research in general. Researchers were encouraged to reflect the truths by emphasizing the importance of the research results and the explanatory way of the application. On the other hand, for analysis, it was first checked by different people whether the data set was entered correctly. Later, the analyses were conducted by different researchers and it was seen that there was consensus about the analyses. In addition, opinions of different experts were taken for the interpretation of the analyses. The analyses were completed with the consensus provided.

\section{FINDINGS}

\section{Research Question 1}

Findings for first research question is summarized in Table 2. When we look at the classes' average levels for attitude toward problem solving, average levels for total attitude change between 14.38 and 17.03, averages for willingness dimension change between 4.11 and 5.24, averages for persistence dimension change between 4.73 and 5.50, averages for persistence dimension change between 4.73 and 5.50, and averages for confidence dimension change between 5 and 6.32 .

When we examine teacher belief scores, total score change between 184 and 253, emotional dimension levels change between 83 and 105, behavioral dimension levels change between 39 and 64, development dimension levels change between 26 and 39 , institutional dimension levels change between 9 and 13, cognitive dimension levels change between 16 and 21 , and education dimension levels change between 7 and 13.

Table 2. Teachers' belief scores with classes' mean values for attitude toward problem solving

\begin{tabular}{|c|c|c|c|c|c|c|c|c|c|c|c|c|c|c|c|c|}
\hline \multirow[b]{2}{*}{ Class } & \multirow[b]{2}{*}{$\mathbf{N}$} & \multicolumn{2}{|c|}{$\begin{array}{c}\text { Students' } \\
\text { Willingness }\end{array}$} & \multicolumn{2}{|c|}{$\begin{array}{c}\text { Students' } \\
\text { Persistence }\end{array}$} & \multicolumn{2}{|c|}{$\begin{array}{c}\text { Students' } \\
\text { Confidence }\end{array}$} & \multicolumn{2}{|c|}{$\begin{array}{c}\text { Students' } \\
\text { Total Attitude } \\
\text { Score }\end{array}$} & \multirow[t]{2}{*}{ 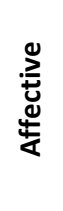 } & \multirow[t]{2}{*}{$\begin{array}{l}\bar{\pi} \\
\frac{0}{2} \\
\frac{0}{0} \\
0 \\
0\end{array}$} & \multirow[t]{2}{*}{ 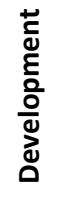 } & \multirow[t]{2}{*}{ 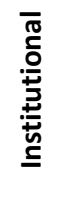 } & \multirow[t]{2}{*}{ 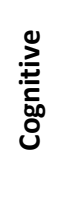 } & \multirow[t]{2}{*}{ 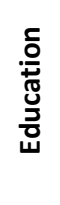 } & \multirow[t]{2}{*}{$\frac{\frac{\varepsilon}{\pi}}{\frac{\pi}{0}}$} \\
\hline & & Mean & sd & Mean & sd & Mean & sd & Mean & sd & & & & & & & \\
\hline 1 & 16 & 4.19 & 1.87 & 5.25 & 1.24 & 5.50 & 2.10 & 14.94 & 4.06 & 96 & 59 & 36 & 11 & 19 & 12 & 233 \\
\hline 2 & 19 & 4.11 & 2.08 & 5.05 & 1.22 & 5.37 & 2.63 & 14.53 & 4.97 & 88 & 54 & 31 & $\underline{13}$ & 19 & 10 & 215 \\
\hline 3 & 39 & 4.82 & 1.43 & 5.18 & 1.17 & 5.18 & 1.75 & 15.18 & 3.37 & 89 & 54 & 32 & 11 & 18 & 12 & 216 \\
\hline 4 & 37 & 4.57 & 1.41 & 5.46 & 0.96 & 5.49 & 2.27 & 15.51 & 3.73 & 88 & 50 & 30 & 10 & 17 & 9 & 204 \\
\hline 5 & 32 & 4.44 & 1.50 & 4.81 & 1.45 & 5.34 & 1.98 & 14.59 & 4.33 & 103 & 63 & 36 & 12 & $\underline{21}$ & 11 & 246 \\
\hline 6 & 34 & 4.76 & 1.52 & 5.38 & 1.02 & 5.12 & 2.29 & 15.26 & 3.96 & 96 & 53 & 31 & 9 & 17 & 10 & 216 \\
\hline 7 & 37 & 4.38 & 1.60 & 5.00 & 1.35 & 5.00 & 2.01 & 14.38 & 4.24 & 104 & 63 & 38 & 11 & 19 & $\underline{13}$ & 248 \\
\hline 8 & 34 & $\underline{5.24}$ & 1.02 & 5.44 & 1.02 & 5.47 & 2.16 & 16.15 & 3.25 & 94 & 59 & 31 & 12 & 18 & 7 & 221 \\
\hline
\end{tabular}




\begin{tabular}{|c|c|c|c|c|c|c|c|c|c|c|c|c|c|c|c|c|}
\hline \multirow[b]{2}{*}{ Class } & \multirow[b]{2}{*}{$\mathbf{N}$} & \multicolumn{2}{|c|}{$\begin{array}{c}\text { Students' } \\
\text { Willingness }\end{array}$} & \multicolumn{2}{|c|}{$\begin{array}{l}\text { Students' } \\
\text { Persistence }\end{array}$} & \multicolumn{2}{|c|}{$\begin{array}{l}\text { Students' } \\
\text { Confidence }\end{array}$} & \multicolumn{2}{|c|}{$\begin{array}{c}\text { Students' } \\
\text { Total Attitude } \\
\text { Score }\end{array}$} & \multirow[t]{2}{*}{ 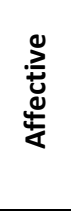 } & \multirow[t]{2}{*}{$\begin{array}{l}\bar{\pi} \\
\frac{0}{2} \\
\frac{\pi}{2} \\
\frac{0}{0} \\
0\end{array}$} & \multirow[t]{2}{*}{ 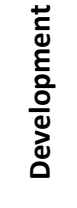 } & \multirow[t]{2}{*}{ 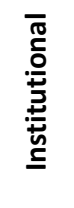 } & \multirow[t]{2}{*}{ 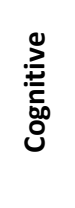 } & \multirow[t]{2}{*}{ 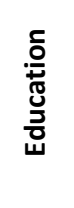 } & \multirow[t]{2}{*}{$\frac{\frac{\varepsilon}{\pi}}{\frac{0}{0}}$} \\
\hline & & Mean & sd & Mean & sd & Mean & sd & Mean & sd & & & & & & & \\
\hline 9 & 37 & 4.86 & 1.48 & 5.19 & 1.39 & 5.57 & 2.23 & 15.62 & 4.23 & $\underline{105}$ & 63 & 34 & 10 & 19 & 12 & 243 \\
\hline 10 & 37 & 5.03 & 1.40 & 5.35 & 1.23 & $\underline{6.32}$ & 2.03 & 16.70 & 4.14 & 83 & 39 & 26 & 11 & 16 & 9 & 184 \\
\hline 11 & 37 & 4.49 & 1.82 & 4.73 & 1.43 & 5.86 & 1.87 & 15.08 & 4.28 & 103 & $\underline{64}$ & $\underline{39}$ & $\underline{13}$ & $\underline{21}$ & $\underline{13}$ & 253 \\
\hline 12 & 36 & 5.22 & 0.83 & $\underline{5.50}$ & 0.85 & 6.31 & 1.72 & $\underline{17.03}$ & 2.35 & 102 & 57 & 36 & 11 & 19 & 9 & 234 \\
\hline Total & 395 & 4.72 & 1.50 & 5.20 & 1.21 & 5.56 & 2.09 & 15.48 & 3.93 & 96.2 & 56.4 & 33.3 & 11.1 & 18.5 & 10.5 & 226 \\
\hline
\end{tabular}

*Lowest scores are in bold italic form and highest scores are in bold underlined form

\section{Research Question 2}

In order to examine second research question, first relationship between teachers' belief subdimensions are controlled. Table 3 shows correlation levels between teacher belief subdimensions calculated for 12 teachers.

Table 3. Correlation levels between teacher belief subdimensions

\begin{tabular}{|c|c|c|c|c|c|}
\hline Subdimensions & 2 & 3 & 4 & 5 & 6 \\
\hline 1. Affective & $0.860 * *$ & $0.813^{*}$ & - & $0.700 *$ & $0.621^{*}$ \\
\hline 2. Behavioral & & $0.864^{*}$ & - & $0.866 *$ & $0.646^{*}$ \\
\hline 3. Development & & & - & $0.854 *$ & $0.740 *$ \\
\hline 4. Institutional & & & & $0.599 *$ & - \\
\hline 5. Cognitive & & & & & $0.586^{*}$ \\
\hline 6. Education & & & & & \\
\hline
\end{tabular}

$* p<0.5 * * p<0.01$

Examining relationship between teachers' belief scores showed that there was only one significant medium size correlation between teachers' institutional scores with teachers' cognitive scores. However other teacher belief sub dimension scores were highly correlated with other teachers' belief scores.

Second process was to examine correlation levels between subdimesion scores of the students' attitudes toward problem solving. Table 4 summarizes correlation levels calculated for 395 students.

Table 4. Correlation between subdimensions of the attitudes toward problem solving

\begin{tabular}{lcc}
\hline First Subdimension & \multicolumn{2}{c}{ Second Subdimension } \\
\cline { 2 - 3 } & Persistence & Confidence \\
\hline Willingness & $0.531^{* *}$ & $0.517^{* *}$ \\
Persistence & & $0.434^{* *}$ \\
\hline
\end{tabular}

$* * \mathrm{p}<0.01$

Analysis showed that students' subdimension scores for attitudes toward problem solving correlated with each other significantly. However, correlation levels were in medium level.

Third analysis for third research question were conducted to analyse the relationship between teachers' belief scores and students' level of attitude toward problem solving. Since there were 395 students and 12 teachers, it is imposible to conduct correlation analysis directly between teacher beliefs and students' attitude toward problem solving. To overcome this situation, classes' average problem solving scores used for corresponding teacher. Therefore, Table 2 constituted the data of this part. Results for this analysis represented in Table 5. 
Table 5. Correlation between attitudes toward problem solving subdimensions averages and teacher belief subdimensions

\begin{tabular}{lcccc}
\hline Belief Subdimentions & Willingness & Persistence & Confidence & Total Attitude \\
\hline Affective & - & - & - & - \\
Behavioral & - & - & - & - \\
Development & - & $-.592^{*}$ & - & - \\
Institutional & - & $-.597^{*}$ & - & - \\
Cognitive & - & $-.784^{* *}$ & - & - \\
Education & $-.578^{*}$ & $-.715^{* *}$ & - & $-.639^{*}$ \\
Belief total & - & $-.621^{*}$ & - & - \\
\hline
\end{tabular}

Correlation results on Table 6 showed that Persistence average scores were mostly correlated with teachers' belief subdimension scores, however the relationship between Persistence and teacher belief subdimensions were negative. In addition to this finding, only Education subdimension scores of the teacher beliefs showed significant relationship to classes' Willingness and Total attitude scores.

\section{Research Question 3}

In order to understand the collective effect effect of teacher belief subdimension scores on classes problem solving attitude averages, regression analysis condected for each subdimension of problem solving attitude.

Regression analysis results showed that class average for Willingness scores could not be estimated significantly using teachers' belief subdimension scores. However, classes' Persistence averages and Confidence averages estimated significantly using some of the subdimension scores of the teachers' beliefs.

Regression analysis for class averages for Persistence scores are reported on Table 6, and it shows that $85 \%$ of the classes' Persistence average values can be estimated using Development, Cognitive and Education subdimensions of the teacher beliefs.

Table 6. Regression analysis results for persistence class averages

\begin{tabular}{|c|c|c|c|c|c|c|c|}
\hline \multirow{2}{*}{ Variables in Regression } & \multicolumn{2}{|c|}{ Unstandardized Coefficients } & \multirow{2}{*}{$\begin{array}{c}\begin{array}{c}\text { Standardized } \\
\text { Coefficients }\end{array} \\
\text { Beta }\end{array}$} & \multirow[t]{2}{*}{$\mathbf{t}$} & \multirow[t]{2}{*}{ p-value } & \multirow[t]{2}{*}{$\mathbf{F}^{\mathbf{a}}$} & \multirow[t]{2}{*}{$\mathbf{R}^{\mathbf{2}}$} \\
\hline & B & Std. Error & & & & & \\
\hline (Constant) & 7.821 & .434 & & 18.003 & .000 & \multirow{4}{*}{$16.090 * *$} & \multirow{4}{*}{0.858} \\
\hline Development & .051 & .019 & .767 & $2.642 *$ & .030 & & \\
\hline Cognitive & -.184 & .043 & -1.094 & $-4.264 * *$ & .003 & & \\
\hline Education & -.086 & .024 & -.635 & $-3.525 * *$ & .008 & & \\
\hline
\end{tabular}

${ }^{*} \mathrm{p}<0.05 \quad * * \mathrm{p}<0.01 \quad$ aDependent variable is Persistence

Regression analysis on class averages for Persistence dimension also showed that, when all teacher belief subdimensins are considered collectively, Cognitive belief scores and Education belief scores affect Persistence scores negatively while Development belief scores affect Persistence scores positively.

Regression analysis for class averages for Confidence scores are reported on Table 7, and it shows that 61\% of the classes' Confidence average values can be estimated using Affective, Behavioral and Institutional Education subdimensions of the teacher beliefs.

Table 7. Regression analysis results for confidence class averages

\begin{tabular}{|c|c|c|c|c|c|c|c|}
\hline \multirow{2}{*}{ Variables in Regression } & \multicolumn{2}{|c|}{$\begin{array}{l}\text { Unstandardized } \\
\text { Coefficients }\end{array}$} & \multirow{2}{*}{$\begin{array}{c}\begin{array}{c}\text { Standardized } \\
\text { Coefficients }\end{array} \\
\text { Beta }\end{array}$} & \multirow[t]{2}{*}{$\mathbf{t}$} & \multirow[t]{2}{*}{ p-value } & \multirow[t]{2}{*}{$\mathbf{F}^{\mathbf{a}}$} & \multirow[t]{2}{*}{$\mathbf{R}^{2}$} \\
\hline & B & Std. Error & & & & & \\
\hline (Constant) & 1.217 & 1.928 & & .631 & .546 & \multirow{4}{*}{$4.253^{*}$} & \multirow{4}{*}{0.614} \\
\hline Affective & .083 & .029 & 1.479 & $2.877^{*}$ & .021 & & \\
\hline Behavioral & -.109 & .032 & -1.846 & $-3.452 * *$ & .009 & & \\
\hline Institutional & .225 & .092 & .634 & $2.451^{*}$ & .040 & & \\
\hline
\end{tabular}

${ }^{*} \mathrm{p}<0.05 \quad * * \mathrm{p}<0.01 \quad{ }^{a}$ Dependent variable is Confidence 
Regression analysis on class averages for Confidence dimension also showed that, when all teacher belief subdimensins are considered collectively, Behavioral belief scores affect Confidence scores negatively while Affective and Institutional belief scores affect Confidence scores positively.

\section{DISCUSSION AND CONCLUSION}

In this study, first aim was to determine professional beliefs of primary school teachers. Research results are given according to sub dimensions of Professional belief scale. Affective, behavioral, development and cognitive sub dimensions are highly correlated among each other. Especially development sub dimension was highly correlated with other dimensions except for the Institutional dimension. Institutional sub dimension was not correlated with other sub dimensions except for the cognitive sub dimension. Education sub dimension was only highly correlated with development sub dimension. teachers' average scores for affective and behavioral dimensions were higher than cognitive and educational. Even though it was not tested explicitly, Table 2 shows that teachers' professional beliefs concentrated mostly on affective sub dimension and it's followed by behavioral sub dimension. Teachers' professional beliefs concentrated less on institutional and educational sub dimensions. This finding suggest that education in primary schools administered more on affective aspects rather than intellectual aspects. Johnston, Mckeown and Mcewen (1999) stated that teaching profession is chosen usually for internal reasons. Similarly, Saban (2003) also stated that teaching profession is chosen by primary school teachers for internal reasons. So, it has been thought that teachers' professional beliefs shaped by the reasons for choosing teaching profession.

Second aim of the study was to investigate the relationship between teachers' professional beliefs and their students' attitude for problem solving. Students' attitude for problem solving is examined to determine this relationship. Examination of students' attitude for problem solving showed that willingness dimension has medium level of correlation with confidence and persistence dimensions while confidence and persistence also correlated with each other in medium level. So correlation between sub dimension of the students' problem solving attitude were significant but in medium level. When the relationship between teachers' professional beliefs and their classes' average attitude for problem solving investigated, willingness dimension of problem solving attitude was only correlated with education dimension of the professional beliefs scale.

On the other hand, persistence scale was highly correlated with, cognitive and education dimensions and medially correlated with development and institutional dimensions. Also it was found that confidence dimension was not significantly correlated to any sub dimension of the professional belief scale when simple point biserial correlation investigated. Another way to investigate the relationship between teachers' professional belief dimension and their classes' average attitude for problem solving sub dimension scores other than simple point biserial correlation is to collectively investigate the relationship between sub dimensions, which is multiple regression analysis.

When all sub dimensions of the teacher professional belief scale taken into consideration, $61 \%$ of the confidence average of the students was explained by affective, behavioral and institutional sub dimensions. Harland and Kinder (1997) put forward that affective outcomes of the teachers such as self-confidence may increase while teachers competence in new knowledge and skills increases. Lieberman and Miler (1991) state that the power of teachers' belief on students' success is more powerful than other variables, and this situation is directly related to professional development. McLaughlin (1991, p. 67) state this as the power and desire for helping the students who are in worst situation. Researcher asserted that teachers' possession of this power related to teachers' belief of effectiveness and this power could be one of the most important concepts of professional development.

\section{SUGGESTION}

In this study, affective dimension of teachers' professional belief has stronger influence than cognitive dimension. This situation can be explored more detailed. Additionally, different methods can be suggested to impact cognitive dimension of the teachers professional beliefs.

\section{LIMITATION}

The sample of the study is consisted of 12 teachers and their fourth grade students from a public school in Hatay province of Turkey. This situation might restricted the some of the results of the correlation analysis since a lot more numbers of teachers required to significantly detect low level of correlation (Faul, Erdfelder, Lang \& Bunchner, 2007).

\section{REFERENCES}

Ashton, P. T. (2015). Historical overview and theoretical perspectives of research on teachers' beliefs. International handbook of research on teachers' beliefs, 31-47.

Barber, M., \& Mourshed, M. (2007). How the world's best-performing school systems come out on top. London: McKinsey and Company. 
Budak, í. (2007). Matematikte üstün yetenekli öğrencileri belirlemede bir model. (Yayınlanmamış doktora tezi). Karadeniz Teknik Üniversitesi, Fen Bilimleri Enstitüsü, Trabzon.

Buyukozturk, S. (2016). Sosyal Bilimler için Veri Analizi El Kitabı İstatistik, Araştırma Deseni SPSS Uygulamaları ve Yorum, PegemA Yayıncılık, Genişletilmiş 22. Baskı, Ankara.

Brown, C. A., \& Cooney, T. J. (1982). Research on Teacher Education: A Philosophical Orientation. Journal of research and Development in Education, 15(4), 13-18.

Chan, K. W. (2004). Preservice Teachers' Epistemological Beliefs and Conceptions about Teaching and Learning: Cultural Implications for Research in Teacher Education. Australian Journal of Teacher Education, 29(1), 1-13.

Chapman, O. (1997). Metaphors in the teaching of mathematical problem solving. Educational studies in Mathematics, 32(3), 201228.

Chong, S., \& Low, E. L. (2009). Why I want to teach and how I feel about teaching-formation of teacher identity from pre-service to the beginning teacher phase. Educational Research for Policy and Practice, 8(1), 59-72.

Clark, C. M., \& Peterson, P. L. (1984). Teachers' Thought Processes. Occasional Paper No. 72.

Enyedy, N., Goldberg, J., \& Welsh, K. M. (2006). Complex dilemmas of identity and practice. Science Education, 90(1), 68-93.

Ernest, P. (1989). The knowledge, beliefs and attitudes of the mathematics teacher: A model. Journal of Education for Teaching, 15(1), 13-34.

Faul, F., Erdfelder, E., Lang, A.-G., \& Buchner, A. (2007). G*Power 3: A flexible statistical power analysis program for the social, behavioral, and biomedical sciences. Behavior Research Methods, 39, 175-191.

Field, A. (2009).Discovering statistics using (3.Edition). London: Sage Publication.

Fraenkel, J. R. ,Wallen, N.E., \& Hyun, H., H. (2012). How to design and evaluate research in education (Eight Edition). NewYork: McGraw-Hill.

Guskey, T. (2002). Professional development and teacher change, Teachers and Teaching: Theory and Practice, 8(3), $381-391$.

Harland, J., \& Kinder, K. (2014). Teachers' continuing professional development: framing a model of outcomes. Professional development in education, 40(4), 669-682.

https://math.berkeley.edu/ gmelvin/polya.pdf, Retrieved from 15.12.2019.

Kagan, D., M. (1992). Implication of research on teacher belief. Educational Psychologist, 27(1), 65-90.

Kane, R., Sandretto, S., \& Heath, C. (2002). Telling half the story: A critical review of research on the teaching beliefs and practices of university academics. Review of educational research, 72(2), 177-228.

Lotter, C., Harwood, W. S., \& Bonner, J. J. (2007). The influence of core teaching conceptions on teachers' use of inquiry teaching practices. Journal of research in science teaching, 44(9), 1318-1347.

McMillan, J. W., \& Schumacher, S. (2014). Research in education: Evidence-based inquiry (Seventh Edition).Boston:Pearson.

National Council of Teachers of Mathematics [NCTM]. (2000). Principles and standards for school mathematics. Reston, VA: NCTM

Olkun, S., \& Toluk-Ucar, Z. (2012). ilköğretimde etkinlik temelli matematik öğretimi (5. Baskı). Ankara: Eğiten Kitap.

Ornstein A.C. \& Lasley, T. J. (2000). Strategies for effective teaching. Boston: McGraw Hill.

Ozgen, B. (2012). Öğretmen ve öğretmen adaylarının mesleki inançları üzerine bir araştırma, (Yayınlanmamış doktora tezi). Marmara Üniversitesi, Eğitim Bilimleri Enstitüsü, İstanbul.

Pajares, M. F. (1992). Teachers" beliefs and educational research: Cleaning up a messy construct. Review of educational research, 62(3), 307-332.

Podell, D. M., \& Soodak, L. C. (1993). Teacher efficacy and bias in special education referrals. The Journal of educational research, 86(4), 247-253.

Putnam, R.T., Lampert, M., \& Peterson, P L. (1990). Alternative perspectives on knowing mathematics in elementary schools. In C. Cazden (Ed.), Review of Research in Education, Vol 16, (pp. 57-150). Washington, DC: American Educational Research Association.

Richardson, V. (1996). The Role of Attitudes and Beliefs in Learning to Teach. J. Sikula, T. Buttery, \& E. Guyton (Eds), Handbook of Research on Teacher Education: A Project of the Association of Teacher Educators (102-119). New York: Macmillan Library Reference.

Richardson, V., Anders, P., Tidwell, D., \& Lloyd, C. (1991). The relationship between teachers' beliefs and practices in reading comprehension instruction. American educational research journal, 28(3), 559-586. 
Schober, P., Boer, C., \& Schwarte, L. A. (2018). Correlation coefficients: appropriate use and interpretation. Anesthesia \& Analgesia, 126(5), 1763-1768.

Sunbul, M., A. (1996). Öğretmen niteliği ve öğretimdeki rolleri. Kuram ve Uygulamada Ĕ̆itim Yönetimi, 8(8), 597-608.

Turkish Republic Ministry of National Education [MoNE]. (2018). ilkokul ve ortaokul matematik dersi öğretim programı. Ankara: Turkish Republic Ministry of National Education.

Turkish Ministry of National Education [MoNE]. (2017). General competencies for teaching profession. Ankara: Turkish Republic Ministry of National Education.

Woolfolk, A. E., Rosoff, B., \& Hoy, W. K. (1990). Teachers' sense of efficacy and their beliefs about managing students. Teaching and Teacher Education, 6(2), 137-148.

Zeichner, K. M. (1983). Alternative paradigms of teacher education. Journal of Teacher Education, 34(3), 3-9. 